\title{
Self-Healing Efforts of Posttraumatic Stress Disorder (PTSD) in the Woman in Cabin 10
}

\author{
Muhammad Hilman Rasyid Yudistira ${ }^{1}$, Sumariella Rusdiarti ${ }^{2}$ \\ \{hilmanbluesky@gmail.com ${ }^{1}$, sumariella@gmail.com² \\ Departemen Susastra, FIB, Universitas Indonesia, Depok, Indonesia ${ }^{12}$
}

\begin{abstract}
Traumatic events often leave a person with fear. Fear that is allowed to continue without realizing it will become a mental disorder called Post Traumatic Stress Disorder (PTSD). PTSD sufferers find it very difficult to escape from the bonds of their past trauma. Therefore, self-healing is needed as a solution to the disorder. This study aims to describe the self-healing process of PTSD in the novel The Woman in Cabin 10. The research method used was qualitative with a trauma theory approach. Based on the results of the research, it can be seen that the special characteristics of PTSD in Laura's character were re-experiencing traumatic experiences (re-experiencing), avoiding feelings of fear (avoidance), and suffering from excessive anxiety (hyperarousal). The self-healing effort in Laura's character was done by fighting self-fear and motivational help from others. Self-healing is an effort to prove yourself and try to break the stereotype of PTSD.
\end{abstract}

Keywords: Trauma, PTSD, anxiety, recovery, stereotypes

Upaya Penyembuhan Diri terhadap Post Traumatic Stress Disorder (PTSD) dalam the Woman in Cabin 10

\begin{abstract}
Abstrak. Peristiwa traumatis sering kali meninggalkan ketakutan di dalam diri seseorang. Ketakutan yang dibiarkan berkelanjutan tanpa disadari akan menjadi sebuah gangguan mental yang disebut Post Traumatic Stress Disorder (PTSD) atau gangguan stres pascatrauma. Penderita PTSD sangat sulit untuk terlepas dari jeratan trauma masa lalunya. Oleh karena itu, diperlukan penyembuhan-diri sebagai solusi atas gangguan tersebut. Penelitian ini bertujuan untuk menguraikan proses penyembuhan diri dari PTSD dalam novel The Woman in Cabin 10. Metode penelitian yang digunakan adalah kualitatif dengan pendekatan teori trauma. Berdasarkan hasil penelitian dapat diketahui bahwa ciri perilaku khusus PTSD pada tokoh Laura adalah mengalami kembali pengalaman traumatis (re-experiencing), menghindari perasaan takut (avoidance), dan menderita kecemasan berlebih (hyperarousal). Upaya pemulihan diri pada tokoh Laura dilakukan dengan cara melawan ketakutan diri dan bantuan motivasi dari orang lain. Penyembuhan diri merupakan upaya pembuktian diri dan usaha mematahkan stereotipe PTSD.
\end{abstract}

Kata Kunci: trauma, PTSD, kecemasan, pemulihan diri, stereotipe 


\section{Pendahuluan}

Manusia tidak pernah lepas dari masa lalunya. Masa lalu yang buruk maupun baik akan membawa kesan dan selalu teringat hingga saat ini. Maka tidak salah untuk dikatakan bahwa masa lalu dapat membentuk watak dan bahkan dapat berpengaruh bagi masa depan seseorang. Peristiwa dan kejadian di masa lalu yang berbentuk pengalaman traumatis yang biasa terjadi seperti peristiwa bencana alam, tragedi peperangan, penculikan, perampokan, kecelakaan serta insiden- insiden lain yang berbekas di benak, seringkali membuat seseorang menjadi ketakutan jika teringat akan masa lalu itu. Ketakutan tersebut biasa dikenal dengan istilah trauma. Apabila trauma tersebut terus dibiarkan menjalar di dalam diri seseorang secara tidak disadari trauma ini akan berubah menjadi trauma berkelanjutan, atau biasa dikenal dengan PTSD (Post Traumatic Stress Disorder) [1].

Salah satu cara untuk melihat pengalaman traumatis berkelanjutan tersebut adalah melalui karya sastra. Ruth Ware merupakan salah satu penulis asal Inggris yang banyak menulis tentang permasalahan traumatis di dalam karya-karyanya. The Woman in Cabin 10 merupakan novel karyanya yang diterbitkan secara global pada tahun 2017. Novel ini menceritakan perjalanan seorang jurnalis penderita PTSD bernama Laura Blacklock, yang ditugaskan untuk meliput sebuah kapal pesiar bernama Aurora.

Pada sebuah penelitian diperlukan adanya kajian pustaka. Kajian pustaka berfungsi untuk memberikan pemaparan tentang penelitian dan analisis sebelumnya yang telah dilakukan. Penelitan yang dapat dijadikan acuan, bandingan, serta tolak ukur untuk penelitian ini. Meskipun, belum banyak dan bahkan belum ada penelitian yang menjadikan The Woman in Cabin 10 sebagai fokus penelitiannya. Namun, peneliti menemukan beberapa penelitian terdahulu dengan topik yang sama yaitu feminisme dan gender yang menjadikan karya sastra bergenre sama, yaitu thriller psikologis sebagai fokus penelitiannya [2].

Yang pertama ialah penelitian dari Mey, L.D. [2]. Penelitian tersebut berfokus pada repsesentasi trauma di dalam novel Awake in The Dark dan keterkaitannya dengan pengarang. Menggunakan teori trauma and madness dari Anthony Morrison untuk menganalisis permasalahan trauma di dalam novel. Hasil dari penelitian tersebut adalah terdapat keterkaitan antara trauma yang dituangkan Shira Nayman di dalam novelnya dengan pengalaman traumatis akan holocaust dan perang dunia. Selain itu terdapat penelitian dari dr. Joanna Stolarek [3]. Penelitian tersebut bertujuan untuk menguji unsur-unsur ketegangan dan ketegangan psikologis dalam novel Patricia Highsmith pada dua karyanya yang terkenal, yaitu Strangers on a Train dan The Talented Mr. Ripley. Hasil penelitian tersebut adalah novelnovel karya penulis Amerika, seperti Miss Highsmith, memiliki kekhasan yang membuat karya-karyanya begitu melejit dan terkenal di pasaran. Penulis menjelaskan bahwa Highsmith mampu menciptakan dunianya sendiri, dunia yang penuh pengalaman klaustropobia, irasional, yang membuat pembacanya selalu berada dalam perasaan khawatir dan bahaya.

Berbeda dari penelitian-penelitian sebelumnya, penelitian ini tidak hanya membahas permasalahan trauma dan keterkaitannya dengan lingkungan, pengalaman pengarang akan permasalahan trauma, ataupun mengulas tentang gejala dan akibat dari Post Traumatic Stress Disorder yang memperngaruhi kepribadian tokoh. Penelitian ini selain melanjutkan penelitian sebelumnya tentang konstruksi penderita PTSD, juga lebih berfokus pada upaya penyembuhan diri (self healing) yang terjadi pada penderita PTSD dalam novel tersebut. 


\section{Metode}

Penelitian ini menggunakan metode kualitatif dengan teori trauma dari Cathy Caruth dan konsep PTSD dari Catty dan Byrne untuk menjelaskan konstruksi penderita PTSD. Pendekatan naratif tokoh dan penokohan digunakan untuk menguraikan peran dan kedudukan tokoh di dalam novel, sedangkan konsep trauma dan PTSD digunakan untuk menganalisis upaya-upaya pemulihan diri tokoh pengidap PTSD.

Terdapat beberapa tahapan dalam penelitian ini. Pertama, peneliti menganalisis bentuk dari PTSD, yaitu perilaku khas penderita PTSD berdasarkan pada ciri-ciri yang telah disebutkan. Kedua, peneliti menganalisis upaya pemulihan yang dilakukan tokoh penderita PTSD di dalam novel, yaitu Laura. Ketiga, peneliti menganalisis makna di balik proses pemulihan diri yang dilakukan penderita PTSD di dalam novel.

\section{Hasil dan Pembahasan}

\subsection{Tokoh dan Penokohan}

Tokoh adalah pelaku dalam sebuah cerita. Tokoh biasanya diperankan oleh tokoh manusia, akan tetapi suatu objek, binatang, atau sesuatu yang menunjukan simbol. Tokoh juga dapat direpresentasikan sebagai manusia (dimanusiakan) dan dianggap sebagai tokoh-tokoh cerita. Seorang tokoh merupakan kumpulan dari beberapa karakteristik, yaitu psikologi, moral, dan sosial. Kemudian, kumpulan karakteristik tersebut membentuk gambaran seorang tokoh (penokohan) [4].

Sedangkan penokohan adalah para tokoh yang berada dalam sebuah cerita. Pada umumnya, manusia menjadi peran utama dalam sebuah cerita, namun ada pula yang tokohnya berasal dari benda, binatang, antitas (misal keadilan, kematian, dan sebagainya). Untuk mendefinisikan pengertian sifat serta karakteristik dan memudahkan pengidentifikasian tokoh, Aminudin berpendapat dalam bukunya Pengantar Apresiasi Sastra [5], bahwa tokoh dapat dimaknai sebagai pemeran atau pelaku yang membawa peristiwa dalam cerita fiksi. Sehingga, peristiwa tersebut dapat menjadi suatu cerita, sedangkan penokohan adalah cara yang dilakukan pengarang untuk menampilkan tokoh.

\subsection{Trauma}

Trauma yang hadir atau terjadi dalam diri seseorang disebabkan oleh pengalaman masa lalu atas peristiwa traumatis yang membuat jiwa seseorang menjadi goyah, tidak stabil, atau terkejut yang diikuti dengan sukarnya menerima kejadian buruk tersebut menjadi bagian dari hidupnya. Pada dasarnya, teori trauma adalah rumpun dari ilmu psikologi sastra yang juga berfokus pada masalah kejiwaan, khususnya trauma. Istilah trauma berasal dari Bahasa Inggris yang dikenal sebagai "wound", dan dalam Bahasa Yunani, istilah "trauma" bermakna cedera atau luka yang terdapat pada tubuh. Di kemudian hari, terjadi perubahan makna di dalam dunia psikologi atau kedokteran yang dipengaruhi oleh Sigmund Freud. Trauma dipahami bukan sebagai luka atau cedera pada tubuh atau raga, namun luka atau cedera pada jiwa atau pikiran atau mental seseorang. Luka yang dialami bukan seperti luka pada tubuh yang mudah dan dapat disembuhkan dalam durasi waktu cukup singkat. Luka ini merupakan luka batin 
yang berasal dari sebuah peristiwa atau pengalaman hidup yang melibatkan unsur waktu, diri, dan lingkungan [6].

\subsection{Konsep Penderita PTSD}

Carter \& Byrne [7] menyatakan bahwa PTSD adalah suatu gangguan yang mengikuti trauma berat yang dialami oleh seseorang dalam usahanya untuk pulih. Penderita PTSD pada umumnya memiliki gejala-gejala yang khas, seperti Re-experiencing (pengalaman kembali), Avoidance(Penghindaran) dan Hyperarousal (kecemasan berlebih).

a. Re-experiencing atau Intrusion adalah kehadiran kembali suatu peristiwa atau pengalaman traumatis ke dalam diri (flashback). Gejala tersebut memunculkan rasa takut, cemas dan kebingungan karena penderita seolah-olah diajak merasakan kembali pengalaman buruk itu.

b. Avoidance ialah perasaan tidak nyaman atau menyakitkan yang dimiliki penderita PTSD. Perasaan tersebut membuat seseorang berusaha menghindar supaya tidak mengalami kejadian traumatis. Hal tersebut terjadi ketika berhubungan atau menjalin relasi dengan orang lain. Penderita akan menghindari kontak emosi dengan keluarga atau sahabat, menghindari lokasi, percakapan yang mengingatkan dirinya dengan trauma, menciptakan "jarak" atau menarik diri dari hal-hal di sekitarnya, bahkan kehilangan minat terhadap berbagai hal yang positif.

c. Hyperarousal adalah kecemasan berlebih yang dialami oleh penderita PTSD. Hal tersebut menyebabkan penderita merasa berada dalam keadaan terancam atau dalam bahaya yang terus menerus terjadi. Seringkali ditemui para penderita mengalami gejolak emosi yang tidak stabil, seperti menjadi agresif secara tiba-tiba, mudah tersinggung, marah yang meledak-ledak, gelisah, sulit konsentrasi, mudah terkejut, panik, dan sebagainya. Hal tersebut dilakukan untuk melindungi dirinya sendiri. Selain itu, penderita juga mengalami insomnia yang disertai dengan mimpi buruk [7].

\subsection{Pemulihan terhadap Trauma}

Tri Kurnia Nurhayati [7] menyatakan bahwa pulih dapat diartikan sebagai keadaan semula, atau sembuh atau baik kembali. Memulihkan artinya memulangkan atau mengembalikan kepada keadaan semula. Jadi pemulihan dapat diartikan sebagai pengembalian sesuatu kepada keaadaan semula. Sondang Irene E. Sidabutar [7] menyatakan bahwa, istilah pemulihan berasal dari dua kata dalam Bahasa Inggris yang dapat diartikan sebagai pemulihan dalam Bahasa Indonesia, yakni recovery dan healing.

Healing dapat diartikan "to make whole" proses untuk mengembalikan menjadi satu kesatuan. Kata healing memiliki akar kata health. Health atau whole adalah kata dalam bahasa inggris yang bermakna membuat menjadi baik atau sehat kembali, kembali pada situasi awal atau semula, membuat luka menjadi tertutup, membebaskan dari duka, dan hal-hal buruk lainnya. Recovery dapat dimaknai sebagai pengembalian sesuatu yang telah hilang, menjadi sehat kembali, serta menjadi sadar kembali yang didapat melalui pengendalian dan keseimbangan. Recovery dapat dimaknai sebagai situasi kembali pada kondisi yang normal, setelah mengindap penyakit, gangguan mental atau luka, atau kembali kepada keadaan fungsi yang sebelumnya. Kedua kata tersebut memiliki penjelasan bahwa kondisi manusia masih dapat Kembali, meskipun telah dihadapkan dengan pengalaman traumatis apabila individu tersebut memiliki pengendalian diri dan keseimbangan yang baik. 


\subsection{PTSD pada tokoh dalam novel The Woman in Cabin 10 karya Ruth Ware 3.5.1. Re-experiencing}

Re-experiencing atau intrusion merupakan kemunculan kembali peristiwa traumatis dalam diri seseorang yang telah mengalami trauma berkelanjutan. Perilaku re-experincing pada novel The Woman in Cabin 10 pada tokoh Laura terjadi ketika Laura mendapat kunjungan polisi.

I was halfway to the living room with my tea when there was a banging at the door-so loud in the silent, echoing flat that I tripped and then froze, half standing, half crouching in the doorway.

...

"Just a minute!" I yelled, suddenly furious and close to tears. "I'm coming! Will you stop banging the bloody door!" (Ware, [8] p.11)

Polisi yang menggedor pintu dengan keras, membuat Laura berdiri membeku, di depan pintu. Gedoran kuat dari pintu mengingatkan kembali kejadian perampokan yang membuat luka fisik dan batin dari dirinya. Sang perampok diketahui mendobrak pintu dengan keras tepat di depan wajah Laura dan menyebabkan luka sayatan di pipinya. Luka tersebut didapatkan karena dobrakan pintu yang membuat pintu terbuka tiba-tiba mengenai wajahnya. Ketika Laura mengalami suatu peristiwa, melihat benda, dan melihat seseorang yang membawa memori pahit tentang perampokan, Laura selalu dihantui rasa ketakutan yang amat sangat, rasa kekhawatian yang berlebih, dan kepanikan yang tiada tara, seperti menangis tibatiba, berkeringat dingin, tidak sadar, berhalusinasi, dan susah tidur.

\subsubsection{Avoidance}

Avoidance atau penghindaran diri dilakukan karena adanya perasaan tidak nyaman atau menyakitkan yang membuat penderita PTSD menghindar, agar dirinya tidak terluka kembali. Salah satu contoh dari perilaku penghindaran yang ditunjukkan di dalam novel adalah ketika keluar di malam hari karena takut untuk kembali ke rumah.

The streets at midnight weren't empty, but they weren't the same ones I trod every day on my way to work, either....

I should have felt afraid-a thirty-two-year-old woman, clearly wearing pajamas, wandering the streets in the small hours. But I felt safer out here than I did in my flat. Out here, someone would hear you cry. (Ware, [8] p.22)

Laura berjalan menyusuri jalanan kota London dengan masih mengenakan baju tidurnya. Ia menghindari untuk berada di rumahnya karena takut akan bayangan perampok yang selalu bersarang di pikirannya. Laura berangan-angan perampok datang kembali ke kamarnya, kembali menyakitinya, dan bahkan membunuhnya. Ia merasa lebih aman berada di jalanan daripada berdiam diri di rumahnya karena ketika berada di luar rumah, seseorang akan dapat mendengar teriakan atau permintaan tolong. Hal tersebut belum tentu dapat Laura lakukan ketika berada di dalam rumah, perampok mungkin akan menyekap Laura, menutup mulutnya dengan kain atau lakban, dan tentu tidak membiarkan Laura berteriak meminta tolong. 


\subsubsection{Hyperarousal}

Hyperarousal atau kecemasan berlebihan muncul dalam diri penderita yang disebabkan oleh kondisi yang mengganggu, mengancam atau berbahaya. Kondisi tersebut biasanya adalah sebuah keadaan yang dapat mengingatkan kembali akan peristiwa traumatis. Di dalam novel kondisi kecemasan tersebut terjadi ketika Laura berhalusinasi melihat perampok di rumah tunanganya, Ben Howard.

The man's hand was over my mouth now, smothering me, the weight of him choking me, and with all my strength, I lifted up the heavy lamp and brought it crashing down.

“Lo, it's me. It's me for Christ's sake, stop!"

What?

Oh God. (Ware, [8] p.24)

Setelah kejadian perampokkan yang dialami Laura, ia hampir tidak bisa tidur selama berhari-hari karena ketakutan dan kekhawatiran akan kedatangan perampok yang mungkin kembali ke rumahnya. Kecemasan berlebihan tersebut membuat Laura sulit tidur, dan bahkan Laura seringkali berhalusinasi akan sosok perampok yang mendatanginya. Kejadian tersebut seperti dijelaskan dalam kutipan di atas. Narasi tersebut menjelaskan bahwa Laura berhalusinasi akan perampok yang mendatanginya di kediaman tunangannya. Laura yang ketakutan memukul dengan membabi buta dengan menggunakan lampu kamar sosok perampok tersebut yang ternyata adalah tunangannya sendiri, Jude Lewis.

\subsection{Upaya pemulihan diri pada tokoh dalam novel The Woman in Cabin 10 karya Ruth Ware}

Pemulihan dapat diartikan sebagai pengembalian sesuatu kepada keaadaan semula. Narasi teks menjelaskan bahwa Laura melakukan berbagai usaha untuk memulihkan dirinya dari penyakit PTSD yang terus membayanginya. Novel memang tidak menjelaskan bahwa Laura sepenuhnya bebas dari PTSD, namun Laura tidak berdiam diri dan melakukan upaya untuk melawan ketakutannya tersebut. Selain dengan usaha melawan ketakutan diri, usaha pemulihan diri penderita PTSD juga tentunya memerlukan bantuan dari orang lain.

\subsubsection{Melawan Ketakutan Diri}

Mengacu pada konsep PTSD yang dijelaskan oleh Carter and Byrne, ia menjelaskan bahwa salah satu gejala pengidap PTSD adalah melakukan avoidance (penghindaran). Orang yang menderita PTSD selalu menghindari tempat- tempat traumatis, orang-orang, benda, maupun segala peristiwa yang membuat penderita kembali mengingat kejadian tersebut. Tokoh Laura yang mengidap PTSD berupaya melawan ketakutannya. Seperti dalam kutipan berikut,

He was about forty or thereabouts, and tall enough to have to stoop as he took a step forward into the doorway, with rumpled hair that looked like he'd only just got out of bed, and eyes so startlingly blue that it looked almost as if he were wearing colored 
contacts. I was staring at them when I realized, suddenly, that he was holding out a hand. (Ware, [8] p.10)

Kutipan di atas menjelaskan bahwa tokoh Laura seharusnya menjadi sangat depresi dan menghindari tempat-tempat, dan orang-orang yang membawa kembali memori traumatik ke dalam dirinya. Namun, Laura tetap menghadapinya. Hal tersebut dapat terlihat seperti menghadapi penjaga kapal yang memiliki perawakan yang sangat mirip dengan perampok yang membuatnya trauma. Hal tersebut juga menjelaskan bahwa terdapat usaha untuk melawan ketakutan akan suatu peristiwa atau objek yang membuatnya teringat kembali akan kejadian traumatis. Seorang penderita PTSD akan selalu melakukan penghindaran (avoidance) terhadap hal-hal yang membawa kembali ingatan traumatis.

\subsubsection{Bantuan dari orang lain}

Selain dari melalui upaya dari diri sendiri, usaha pemulihan juga dapat berupa bantuan dari tokoh-tokoh lain. Laura merupakan seorang penderita PTSD. Seorang penderita PTSD sangat sulit sekali untuk keluar dari memori traumatisnya, maka selain harus berupaya sendiri melawan ketakutannya, pihak-pihak lain, seperti keluarga dan orang-orang terdekat perlu ikut andil dalam membantu memulihkan keadaan tersebut.

“You should learn self-defense," Archer said. "That's how I started, you know. Royal Marines. It's not about size, even a girl like you can overpower a man if you get the leverage right. Look, I'll show you." He pushed back his chair. "Stand up." (Ware, [8] p.74)

Setelah Laura menceritakan kejadikan perampokan yang terjadi di rumahnya, teman Laura seperti Archer memberikannya motivasi. Archer menjelaskan bahwa Laura mungkin dapat mencegah atau melawan perampok itu seandainya Laura mengetahui atau memiliki pengetahuan tentang bela diri. Archer kemudian memotivasi Laura bahwa tidak semestinya ia takut melawan perampok, meskipun perampok itu memiliki ukuran tubuh yang lebih besar, namun jika Laura mengetahui cara terbaik untuk mempertahankan diri dari tindak kejahatan, mungkin Laura dapat meminimalisir hal tersebut untuk terulang kembali. Archer kemudian mengajarkan Laura satu gerakan bela diri yang dapat digunakan ketika mendapatkan penyerangan. Kepedulian Archer adalah salah satu hal yang dapat membuat penderita PTSD sedikit melupakan lukanya akan peristiwa traumatis yang susah untuk dilupakan. Laura bahkan belajar dari Archer cara untuk mempertahan diri, sehingga ia akan siap dan berani untuk menghadapi penyebab utama traumanya, yaitu perampokan.

\subsection{Pemaknaan terhadap self-healing atau upaya pemulihan diri}

Tokoh Laura memiliki pengalaman traumatis yang susah untuk dilupakan. Jika Laura teringat akan pengalamannya tersebut, ia menjadi sangat depresi, menjadi kaku, ketakuan, khawatir, dan menangis. Traumanya tersebut bahkan membuatnya sering berhalusinasi tentang perampok yang mendatanginya. Laura berupaya untuk memulihkan penyakit trauma berkelanjutannya (PTSD) dengan melawan ketakutan akan hal-hal yang membawa memori traumatisnya. Namun di balik semua itu, usaha penyembuhan diri Laura juga dapat dimaknai sebagai sebuah upaya untuk mengubah stigma umum penderita PTSD. Menurut Hatta, K. [7], seseorang yang menderita trauma berkelanjutan (PTSD), akan sangat depresi dan mudah larut 
dalam emosinya. Hal tersebut menyebabkan penderita PTSD kehilangan kepercayaan diri, sering mengucilkan diri dari keramaian, putus asa menghadapi masa depan, dan bahkan memiliki kecenderungan untuk bunuh diri. Secara umum, seseorang penderita PTSD memiliki stigma sebagai orang yang sangat lemah dan rapuh. Maka daripada itu, upaya pemulihan yang dilakukan oleh tokoh penderita PTSD di dalam novel The Woman in Cabin 10, dapat dimaknai sebagai sebuah usaha untuk mendobrak stigma umum menderita PTSD. Usaha pemulihan diri yang digambarkan oleh tokoh Laura, dapat dimaknai sebagai bentuk pembuktian diri penderita PTSD dan usaha untuk mematahkan stereotip penderita PTSD.

\subsubsection{Upaya Mematahkan Stereotip PTSD dan Usaha Pembuktian Diri}

Stereotip dapat dimaknai sebagai konsepsi mengenai sifat suatu golongan berdasarkan prasangka yang subjektif dan tidak tepat [9]. Seorang penderita PTSD memiliki anggapan sebagai individu yang lemah dan sangat rapuh. Namun, upaya pemulihan yang dilakukan Laura tersebut dapat dibaca sebagai upaya untuk mematahkan stereotip penderita PTSD yang lemah. Di dalam novel The Woman in Cabin 10, tokoh Laura yang menderita PTSD, diperlihatkan sebagai tokoh yang kuat. Meskipun ia menderita PTSD, ia tidak digambarkan mudah menyerah dan tetap menghadapi penyakitnya tersebut.

Selain mematahkan stereotip lemah penderita PTSD, upaya pemulihan diri juga dapat dimaknai sebagai sebuah usaha pembuktian diri terhadap orang-orang yang memandang Laura sebelah mata. Dijelaskan bahwa Laura adalah seorang jurnalis yang bertugas untuk meliput perjalanan kapal pesiar Aurora. Pada malam pertama perjalanan Laura di kapal, ia melihat sebuah kasus pembunuhan di dalam kapal. Ketika ia melaporkan kasus tersebut kepada orangorang di dalam kapal, orang-orang tersebut tidak ada yang memercayai kesaksian Laura mengenai kejadian pembunuhan tersebut. Orang-orang tersebut beralasan bahwa kesaksian dari seseorang yang menderita PTSD tidak dapat sepenuhnya dipercaya, karena seorang yang menderita PTSD, sering dianggap tidak bisa membedakan ilusi dan kenyataan. Namun, bukannya menyerah pada keadaan, Laura berupaya untuk menyakinkan orang-orang dengan mengumpulkan bukti-bukti dan fakta kesaksian yang sahih untuk membuktikan kesaksiannya, sampai akhirnya ia bisa meyakinkan orang-orang tersebut. Hal tersebut menjelaskan adanya upaya pemulihan diri melalui pembuktian diri kepada orang-orang di kapal bahwa tidak selalu apa yang dilihat seorang penderita PTSD adalah ilusi.

\section{Simpulan}

Berdasarkan hasil penelitian ini, dapat diketahui bahwa Laura memiliki semua ciri-ciri penderita PTSD, yaitu kemunculan kembali peristiwa traumatis ke dalam diri (Reexperiencing), penghindaran terhadap pemicu trauma (Avoidance), dan kecemasan berlebih (Hyperarousal). Semua ciri-ciri tersebut membuat Laura selalu berada dalam keadaan cemas, depresi atau khawatir, ketika ia berhadapan kembali dengan hal-hal yang dapat memicu trauma berklanjutannya (PTSD).

Namun, Laura melakukan usaha agar dapat lepas dari jeratan penyakit PTSD. Untuk lepas dari bayangan PTSD tersebut, Laura melakukan upaya pemulihan diri (self-healing), yaitu dengan melawan ketakutan diri dan dengan bantuan motivasi orang lain. Motivasi tersebut dapat berasal dari orang-orang terdekat, seperti keluarga dan teman. Salah satu tokoh yang memotivasi Laura adalah Archer, sosok teman dari Laura. 
Penderita PTSD sering dipandang sebelah mata dan lemah oleh masyarakat. Namun, melalui upaya pemulihan diri (self-healing) yang Laura lakukan, seperti melawan ketakutan dirinya atas peristiwa, benda, atau objek-objek pemicu trauma. Tokoh Laura berubah menjadi sosok kuat yang berani melawan semua stigma lemah itu. Maka, upaya pemulihan diri yang dilakukan tokoh Laura dapat dimaknai sebagai sebuah usaha pembuktian diri penderita PTSD dan upaya untuk mendobrak stereotip penderita PTSD yang sering dianggap lemah.

Hasil penelitian ini diharapkan dapat menjadi referensi bagi pembaca untuk menghasilkan karya-karya baru, baik berupa caranya maupun medianya, terutama yang menggunakan teoriteori trauma dan PTSD. Perlu diadakan penelitian lanjutan dengan kajian yang berbeda untuk mengupas segala permasalahn pada novel The Woman in Cabin 10, disebabkan penelitian ini adalah yang pertama terhadap novel karangan Ruth Ware tersebut. Masih banyak aspek lain yang belum pernah dikaji untuk menambahkan wawasan atau pengetahuan kita.

\section{Referensi}

[1] Felman S. The Juridical Unconsciousnes: Trials and Traumas in the Twentieth Century. Cambridge: Harvard University Press, 2002. 171 p.

[2] Mey L.D. The Representation of Trauma in Shira Nayman's Awake in the Dark and The Listener. Gent: Universiteit Gent, 2012.

[3] Stolarek J. Between suspense and psychological thriller-the examination of criminal intrigue, the psychology of guilt and abnormal human behaviour in Patricia Highsmith's Strangers on a Train and The Talented Mr. Ripley. Poland: Siedlce University of Natural Sciences and Humanities, 2014.

[4] Schmitt M, Viala A. Savoir lire. Paris: Didier, 1982. 69 p.

[5] Aminuddin, Pengantar Apresiasi Karya sastra. Malang: Sinar Baru, 1987. 79 p.

[6] Caruth C. Unclaimed experince: trauma, narrative, and history. Baltimore: The John Hopskin University Press, 1996. 4 p.

[7] Hatta K. Trauma dan Pemulihannya. Edisi 1. Banda Aceh: Dakwah Ar-Raniry Press, 2016. 38 p., 113-114 p.

[8] Ware R. The Woman in Cabin 10. London: Penguin Random House, 2016.

[9] https://kbbi.web.id/stereotip, diunduh pada 17 Desember 2019, pukul 22.15. 